\title{
Yield and quality of inflorescences of 'Golden Torch' heliconia in different shaded environments
}

\author{
Rafaela R. de Souza ${ }^{1}$, Márkilla Z. Beckmann-Cavalcante ${ }^{2}$, Alcilane A. Silva ${ }^{3}$, \\ Everaldo M. da Silva ${ }^{3}$, Leonardo P. da S. Brito ${ }^{3}$ \& Adriano O. Silva ${ }^{3}$ \\ ${ }^{1}$ Universidade Federal de Lavras. Lavras, MG. E-mail: rfag.fisio@gmail.com (Corresponding author) \\ ${ }^{2}$ Universidade Federal do Vale do São Francisco. Petrolina, PE. E-mail: markilla.beckmann@univasf.edu.br \\ ${ }^{3}$ Universidade Federal do Piauí. Bom Jesus, PI.E-mail: alcilanearnaldo@gmail.com; everaldo@ufpi.edu.br; leonardbrito@ufpi.edu.br; adrianobj@hotmail.com.br
}

Key words:

flowering

heliconiaceae

luminosity

\begin{abstract}
A B S T R A C T
Light is one of the factors that most affect crop growth and yield. However, the control of light intensity is difficult, because, under certain environmental conditions, light energy may exceed or limit the capacity of plants to use it. In this sense, the productive behavior of plant species in shaded environments needs to be known. This study aimed to evaluate the effect of different shaded environments with black shade nets [ 0 (full sun), 35 and 50\%, and overlap $35+50 \%$ shading nets] on flowering, yield and quality of inflorescences of Heliconia psittacorum (cv. 'Golden Torch'). The shaded environments caused a reduction in the number of days for inflorescence emergence and in the cycle of H. psittacorum (cv. 'Golden Torch'). The yield and quality of inflorescences of plants grown under full-sun conditions ( $0 \%$ shading) were impaired. The results indicate that, for a better management of the crop environment, aiming yield and quality of inflorescences of H. psittacorum (cv. 'Golden Torch'), the use of black shade nets with 50\% shading is recommended.
\end{abstract}

Palavras-chave:

florescimento heliconiaceae luminosidade

\section{Produtividade e qualidade de inflorescências de helicônias 'golden torch' em diferentes ambientes de sombreamento}

\begin{abstract}
RES U M O
A luz é um dos fatores que mais afetam o crescimento e a produtividade das culturas; no entanto, o controle da intensidade luminosa é difícil visto que em determinadas condições ambientais a energia luminosa pode exceder ou limitar a capacidade que a planta tem de utilizá-la; neste sentido, o comportamento produtivo das espécies em ambientes sombreados necessita ser conhecido. Objetivou-se, no presente estudo, avaliar o efeito de diferentes ambientes de sombreamento com telas tipo sombrite de cor preta [0 (pleno sol), 35 e 50\% e sobreposição de telas com malhas de $35+50 \%$ ] sobre o florescimento, produtividade e qualidade de inflorescências de Heliconia psittacorum (cv. ‘Golden Torch’). Os ambientes de sombreamento promoveram redução no número de dias para emissão da inflorescência e no ciclo das plantas de H. psittacorum (cv. 'Golden Torch'). A produtividade e a qualidade de inflorescências das plantas cultivadas em condições de pleno sol (0\% de sombreamento) foram prejudicadas. Os resultados indicam que, para um manejo melhor do ambiente de cultivo visando à produtividade e à qualidade de inflorescências de H. psittacorum (cv. 'Golden Torch') sugere-se a utilização de telas tipo sombrite com malha preta de 50\%.
\end{abstract}




\section{INTRODUCTION}

Currently, floriculture is one of the most important economic activities for the agribusiness in Brazil. Edaphoclimatic conditions in Brazil, especially in the North and Northeast, favor the production of flowers and ornamental plants of excellent quality (Junqueira \& Peetz, 2014). In this context, tropical plants appear as an excellent opportunity for Brazil to expand its agricultural frontiers and increase its capacity to generate employment and income in rural areas (Unemoto et al., 2012; Albuquerque et al., 2014).

Tropical floriculture is a good investment alternative, because it is an activity that requires a small area for cultivation and the plants have short cycle and high added value, which provides the producer with a rapid return on the invested capital (Paulino et al., 2013). Among the tropical species, heliconias stand out as cut flowers, due to their exotic beauty with diversity of colors and shapes, resistance to handling, transport and increased postharvest durability (Rodríguez, 2013; Albuquerque et al., 2014).

The effect of light has been reported as one of the most important factors affecting crop production and development, since it is directly involved in the production of biological energy. Therefore, under certain environmental conditions, the absorbed light energy can be higher or lower than plant capacity to use it, creating an imbalance caused by photoinhibition or light deficiency. Under these conditions, crop development and yield are severely restricted (Ivanov et al., 2008; Daí et al., 2009; Craven et al., 2010).

There is no information on the tolerance and reproductive behavior of Heliconia psittacorum (cv. 'Golden Torch') with respect to shading. Therefore, it is extremely important to evaluate the influence of different shaded environments on yield and quality of inflorescences, in order to obtain information that will allow a better light management in the production environment. Thus, this study aimed to evaluate the effects of shaded environments on flowering, quality and yield of inflorescences of Heliconia psittacorum (cv. 'Golden Torch').

\section{Material ANd Methods}

The experiment was carried out from August 2012 to July 2013 at the Floriculture Sector of the Campus Prof ${ }^{\mathrm{a}}$. Cinobelina Elvas (CPCE), at the Federal University of Piauí (UFPI), in the municipality of Bom Jesus-PI, Brazil (9 $04^{\prime} 45^{\prime \prime}$ S; $44^{\circ} 18^{\prime}$ 46 " W; $322 \mathrm{~m}$ ).

For the seedlings, rhizomes of Heliconia psittacorum (cv. 'Golden Torch') were purchased from the CPCE/UFPI heliconia collection. These rhizomes were standardized, cleaned and, for asepsis, immersed in a solution containing sodium hypochlorite (5\%) for 15 min (Beckmann-Cavalcante et al., 2011). Subsequently, the rhizomes were cultivated in polyethylene containers (volume $3.0 \mathrm{~L}$ ) filled with sand and cattle manure at a $1: 1(\mathrm{v} / \mathrm{v})$ ratio. The seedlings were placed in a greenhouse environment with 50\% shading for 118 days (Beckmann-Cavalcante et al., 2011).

Transplantation to $20-\mathrm{L}$ pots was performed when the seedlings had about 3 to 4 leaves. The pots were filled with substrate containing sand and cattle manure at a 1:1 (v/v) ratio. All pots received a dose of $45 \mathrm{~g}$ of phosphorus (single superphosphate) prior to the transplantation. Fertilization with nitrogen (urea, $45 \%$ ) and potassium (potassium chloride, 58\% $\mathrm{K}_{2} \mathrm{O}$ ) at a dose of $120 \mathrm{~g} \mathrm{pot}^{-1}$ was divided into three applications of $40 \mathrm{~g} \mathrm{pot}^{-1}$ at a 45-day interval (Silva, 2013).

The plants were arranged in four shaded environments, divided according to the following treatments: $1=0 \%$ shading (full sun); 2 = black shade nets with $35 \%$ shading; 3 = black shade nets with $50 \%$ shading and $4=$ overlap of $35+50 \%$ shading nets. The experiment had six replicates and two pots per plot, totaling 48 pots. In the shading treatments, plants were placed in a wooden frame covered on top and on the sides, with black polyethylene screen. Each frame was $9 \mathrm{~m}$ long $x 5 \mathrm{~m}$ wide and $2 \mathrm{~m}$ high.

Irrigation was performed using a drip system with pressurecompensating emitters (nominal flow rate of $4 \mathrm{~L} \mathrm{~h}^{-1}$ ), which were previously measured under normal operating conditions, with $97.8 \%$ distribution uniformity coefficient. The emitters were coupled to irrigation lines consisting of polyethylene tubes with diameter of $16 \mathrm{~mm}$. Irrigation was daily performed, until soil attained field capacity (Gomes et al., 2006).

During the experimental evaluations, there was an incidence of pest insects associated with heliconias, such as Dysmicoccus brevipes (Cockerell), Antichloris eriphia (Fabricius) and Aleurothrixus floccosus (Maskell). The infestation was more concentrated in the environment with the overlap $35+50 \%$ shading nets. As a control measure, four Malatol $^{\circledR}$ injections were applied at a 15-day interval, at a concentration of $5 \mathrm{~mL} \mathrm{~L}^{-1}$ of solution.

Meteorological data of temperature, relative humidity and light intensity were daily monitored during the experiment (Figure 1), using a digital thermo-hygrometer (Quimis ${ }^{\circ}$ ) and a digital lux meter (Instrutherm ${ }^{\bullet}$ ).

The evaluations were performed until 210 days after transplantation. The evaluated variables were: a) Number of days for the emergence of the first tiller (NDET), obtained by daily observation; b) Number of days for the emergence of the first inflorescence (NDEI), number of days from tiller emergence to the emergence of the first inflorescence; c) CYCLE: number of days from tiller emergence until the date of harvest (with at least two open bracts); d) Number of days for inflorescence harvest, from its emergence (NDIH); e) inflorescence length (IL), measured from the colored part of the stalk to the apex of the inflorescence; $f$ ) length of flower stem (LFS), measured from the base of the pseudostem to the apex of the inflorescence; g) diameter of the flower stem (DFS), measured at $20 \mathrm{~cm}$ below the inflorescence; $\mathrm{h}$ ) number of inflorescences per pot (NI/POT), obtained from the direct counting of flowers per pot.

The obtained data were subjected to analysis of variance in order to identify significant effects of the different shaded environments by the "F" test. The means were compared by Tukey test $(\mathrm{p}<0.05)$ and the analyses were performed using the computer program SISVAR (Ferreira, 2011).

\section{RESUlts AND Discussion}

In the present study, there was a beneficial effect of shading on the flowering period, cycle, yield and quality of 


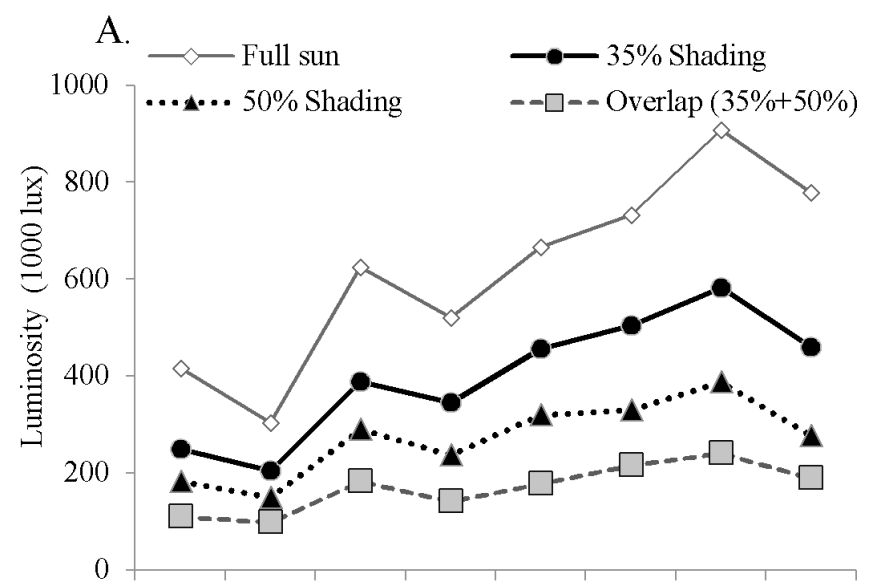

B.
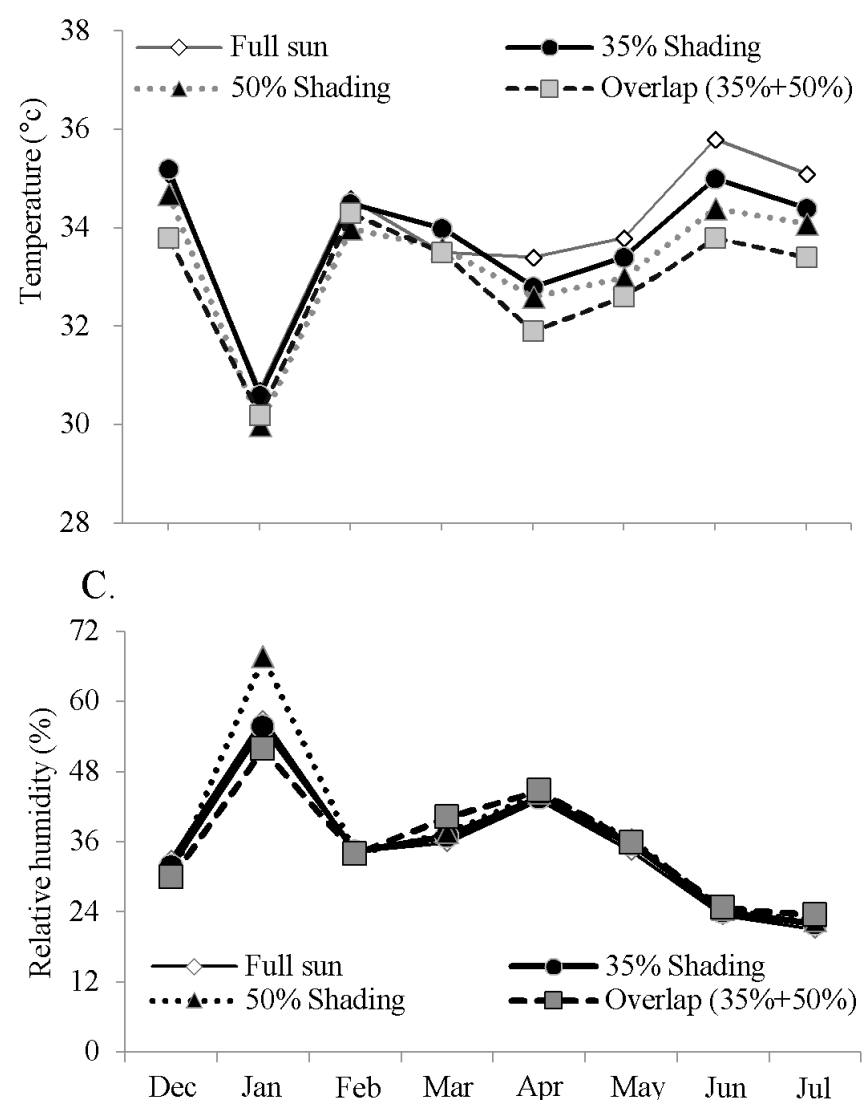

Figure 1. Mean values of luminosity (A), temperature (B) and relative humidity $(\mathrm{C})$ in different shaded environments during the experimental period

H. psittacorum (cv. 'Golden Torch') inflorescences. However, NDET was not affected by shading (Table 1). This result indicates that tiller emergence speed is independent of this factor. Beckmann-Cavalcante et al. (2011) evaluated the effect of different substrates and environmental conditions (full sun and $50 \%$ shading) on the production of heliconia seedlings (Heliconia psittacorum L.) and also found no significant effect of shaded environments on the number of days for the emergence of the first tiller. Albuquerque et al. (2014) evaluated the effect of doses and sources of silicon on yield and development of Heliconia (cv. 'Golden Torch') and also found no significant effect on NDET.

The lack of significant effects for NDET with respect to shading and other factors, such as fertilization, may be related
Table 1. Analysis of variance for the number of days for the emergence of the first tiller (NDET), number of days for the emergence of the first inflorescence (NDEI), plant cycle (CYCLE), number of days for inflorescence harvest (NDIH), inflorescence length (IL), length of flower stem (LFS), diameter of the flower stem (DFS) and number of inflorescences produced per pot (NI/POT) of Heliconia psittacorum (cv. 'Golden Torch') for different shaded environments

\begin{tabular}{|c|c|c|c|c|c|c|c|c|}
\hline \multirow{2}{*}{$\begin{array}{c}\text { Source } \\
\text { of variation }\end{array}$} & NDET & NDEI & CYCLE & NDIH & IL & LFS & \multirow{2}{*}{$\begin{array}{l}\text { DFS } \\
\mathrm{mm}\end{array}$} & \multirow{2}{*}{ NI/POT } \\
\hline & \multicolumn{4}{|c|}{ days } & \multicolumn{2}{|c|}{$\mathrm{cm}$} & & \\
\hline Shading ('F') & $2.1 \mathrm{~ns}$ & $4.2^{*}$ & $4.1^{\star}$ & $3.0 \mathrm{~ns}$ & $4.3^{*}$ & $58.9 * *$ & $44.0^{* *}$ & $52.9 * *$ \\
\hline Overall mean & 32.5 & 111.4 & 119.2 & 12.0 & 18.5 & 67.2 & 5.8 & 4.3 \\
\hline CV (\%) & 35.3 & 34.9 & 36.5 & 11.7 & 7.0 & 8.3 & 7.3 & 17.2 \\
\hline
\end{tabular}

to the availability of reserves in the rhizomes. Therefore, it is possible to state that the intrinsic characteristics of the rhizome can influence tillering rate, more than any other factor related to the environment.

The NDIH was not influenced by shading (Table 1). Although the inflorescences of $H$. psittacorum (cv. 'Golden Torch') grown under full sun reach a harvest point similar to that of plants grown in shaded environments, they show low quality, which is due to injuries, such as burns on the tips of the bracts. This type of injury causes rejection of this product by consumers, besides depreciating its quality (Albuquerque et al., 2014).

According to Ivanov et al. (2008), plants grown in environments with excessive light radiation produce excess energy, which in turn damage the photosynthetic apparatus, due to the formation of destructive oxidant molecules (such as singlet oxygen radicals), resulting from photoinhibition. When the level of production of these molecules is stimulated by stress, plants immediately manifest symptoms such as chlorosis, followed by necrosis and senescence. In this context, excess luminosity should be avoided in $H$. psittacorum (cv. 'Golden Torch') crops, in order to obtain inflorescences with better quality.

In general, shading affected NDEI (Figure 2A). The flowering of plants grown under full-sun conditions $(0 \%$ shading) occurred 159 days after the emergence of the tiller, while plants grown in an environment with $35 \%$ shading flowered after 103 days.

Despite the remarkable decrease in NDEI in the treatment with $35 \%$ shading, compared with the environment with $0 \%$
A

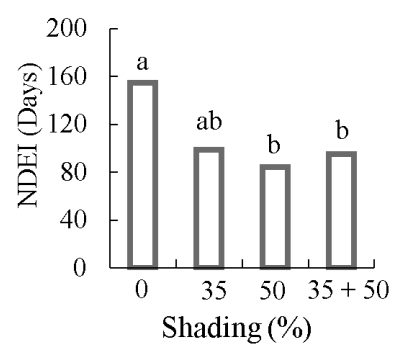

B.

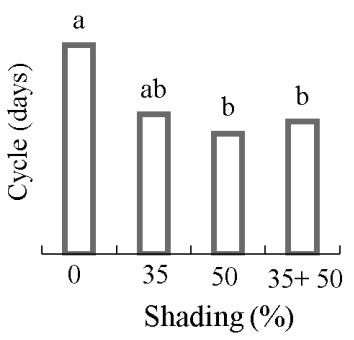

Figure 2. Effect of environmental shading on the number of days for the emergence of the first inflorescence - NDEI (A) and on the cycle (B) of H. psittacorum (cv. 'Golden Torch') 
shading (full sun), these treatments were not statistically different. This result indicates that the decrease in luminous intensity at the level of $35 \%$ is not enough to obtain early flowering. The largest reduction in NDEI was observed for the treatment with $50 \%$ shading (flowering 80 days after the emergence of the tiller); however, it did not differ in the environment with overlap of $35+50 \%$ shading nets. Different studies on H. psittacorum (cv. 'Golden Torch') cultivation have shown that flowering usually occurs between 120 and 170 days (Albuquerque et al., 2010; Beckmann-Cavalcante et al., 2015).

According to the variation in plant cycle (Figure 2B), the treatment with $0 \%$ shading (full sun) showed a cycle of approximately 171 days. This result was similar to that found in the environment with 35\% shading. However, when compared with other shaded environments [50\% (cycle of about 98 days) and $35+50 \%$ overlap (cycle of approximately 109 days)], there was a significant effect. It should be noted that the environment with $50 \%$ shading reduced plant cycle by approximately $45 \%$, compared with the environment with $0 \%$ shading (full sun), a difference of more than 73 days. Thus, the use of shading is beneficial for the production of 'Golden Torch' plants, resulting in earlier flowering. Therefore, it is noted that the parameters NDEI and cycle of $H$. psittacorum (cv. 'Golden Torch') are greatly appreciated by the producers, since the short time for the production of inflorescences provides fast return on the invested capital.

Among the parameters that define the quality of inflorescences, IL is one of the most important characteristics, since it is the most prominent in the arrangements and with the greatest appreciation by the consumer. The environments with shading favored the occurrence of inflorescences with the greatest length (Figure 3A). However, both the environment with $35 \%$ shading and the overlap of $35+50 \%$ shading nets were similar to that found for the environment with $0 \%$ shading (full sun). This result indicates that, although excess luminosity directly affects the development of $H$. psittacorum (cv. 'Golden
A.

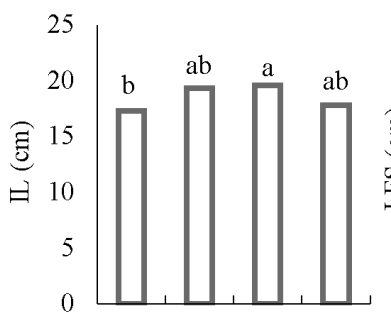

C.

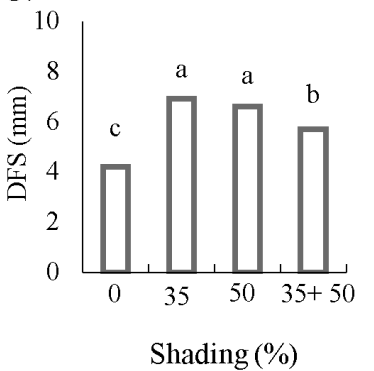

B.

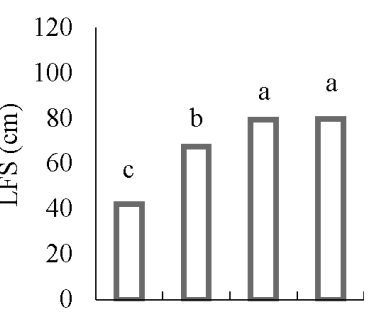

D

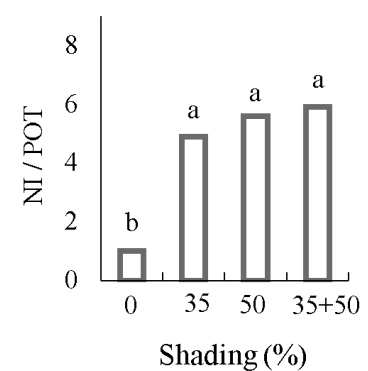

Figure 3. Effect of shaded environments on inflorescence length (A), length of flower stem (B), diameter of flower stem (C) and number of inflorescences per pot (D) of $H$. psittacorum (cv. 'Golden Torch')
Torch') negatively, the availability of low levels of radiation may also reduce growth, due to a lower photosynthetic activity and, therefore, a lower $\mathrm{CO}_{2}$ fixation (Deng et al., 2012).

The LFS of heliconia is also an important characteristic for the flower market. Plants grown in shaded environments (35\% shading and $35+50 \%$ overlap) produced longer stems compared with plants grown under full sun (Figure 3B). From these results, it is possible to state that the length of the stems in treatments with shading responded to market demands for the cultivar 'Golden Torch' since, according to Albuquerque et al. (2010), stems with an average length greater than $70 \mathrm{~cm}$ are ideal for marketing.

According to Figure 3C, the diameter of the flower stem showed a variation from 4.2 to $6.9 \mathrm{~mm}$ in the treatments with 0 and $35 \%$ shading, respectively. In the environment with $50 \%$ shading, DFS was similar to that in the environment with 35\%. It was also found that the environment with $35+50 \%$ overlap reduced DFS by $17 \%$, in comparison to the environment with $35 \%$ shading. Thus, there is a strong reducing trend in DFS for H. psittacorum (cv. 'Golden Torch') plants as shading exceeds $50 \%$. These results are related to that reported by Berry \& Kress (1991) for some heliconia species, since the stems had greater lengths at high shading levels, probably due to etiolation, which is a plant elongation due to the limited light (Deng et al., 2012).

DFS and LFS are very important parameters, determining the quality and resistance of the flower still at the field, especially in relation to winds, transport from the field to the site of treatment and selection, packaging and postharvest durability. In general, the carbon reserve contained in the stem of cut flowers is used to extend their longevity, and the larger the length and the diameter of the stem, the longer their postharvest life (Castro et al., 2007; Asrar et al., 2012; Albuquerque et al., 2014).

The mean values of NI/POT (Figure 3D) ranged from 1 to 5.9. There was a significant difference in all the environments with shading, compared with $0 \%$ shading (full sun). The treatment with $0 \%$ shading produced 4.9 inflorescences less than the treatment with $35+50 \%$ overlap, i.e., a significant difference of $490 \%$. The number of inflorescences is a very important parameter, because the product of heliconias is the flower stem. Therefore, the higher number of produced flower stems enables greater competitiveness and increased profitability for producers (Paulino et al., 2013; Albuquerque et al., 2014; Beckmann-Cavalcante et al., 2015).

By associating the best results in yield and quality of inflorescences (length and diameter of stems) with a better light management in the production environment of $H$. psittacorum (cv. 'Golden Torch'), it was demonstrated that the use of an environment with $50 \%$ shading is the most appropriate.

\section{Conclusion}

For a better light management in the production environment of H. psittacorum (cv. 'Golden Torch') and inflorescences with a higher yield, precocity and quality, the use of black shade nets with $50 \%$ shading is recommended. 


\section{Literature Cited}

Albuquerque, A. W.; Rocha, E. S.; Costa, J. P. V.; Farias, A. P.; Bastos, A. L. Produção de helicônia Golden Torch influenciada pela adubação mineral e orgânica. Revista Brasileira de Engenharia Agrícola e Ambiental, v.14, p.1052-1058, 2010. http://dx.doi. org/10.1590/S1415-43662010001000005

Albuquerque, A. W.; Santos, J. M.; Farias, A. P. Produtividade e qualidade pós-colheita de helicônia Golden Torch submetida a fonte e doses de silício. Revista Brasileira de Engenharia Agrícola e Ambiental, v.18, p.173-179, 2014. http://dx.doi.org/10.1590/ S1415-43662014000200007

Asrar, A. W. A. Effects of some preservative solutions on vase life and keeping quality of snapdragon (Antirrhinum majus L.) cut flowers. Journal of the Saudi Society of Agricultural Sciences, v.11, p.20-35, 2012. http://dx.doi.org/10.1016/j.jssas.2011.06.002

Beckmann-Cavalcante, M. Z.; Amaral, G. C.; Avelino, R. C.; Silva, A. A.; Silva, A. S.; Oliveira, J. B. S. Produção de inflorescências de helicônias cv. Golden Torch sob adubação nitrogenada e potássica. Comunicata Scientiae, v.6, 65-73, 2015.

Beckmann-Cavalcante, M. Z.; Amaral, G. C.; Silva, A. A.; Cavalcante, I. H. L.; Lima, M. P. D. Alternative substrates for production of Heliconia psittacorum L. seedlings under shade and open field conditions. African Journal of Biotechnology, v.10, p.15272-15277, 2011. http://dx.doi.org/10.5897/AJB11.1028

Berry, F.; Kress, W. J. Heliconia: An identification guide. Washington: Smithsonian Institution, 1991. 334p.

Castro, A. C. R.; Loges, V.; Costa, A. S.; Castro, M. F. A.; Aragão, F. A. S.; Willadino, L. G. Hastes florais de helicônia sob deficiência de macronutrientes. Pesquisa Agropecuária Brasileira, v.42, p.1299-1306, 2007. http://dx.doi.org/10.1590/S0100204X2007000900012

Craven, D.; Gulamhussein, S.; Berlyn, G. P. Physiological and anatomical responses of Acacia koa (gray) seedlings to varying light and drought conditions. Environmental and Experimental Botany, v.69, p.205-213, 2010. http://dx.doi.org/10.1016/j. envexpbot.2010.04.002
Daí, Y.; Shen, Z.; Liu, Y.; Wang, L.; Hannaway, D.; Lu, H. Effects of shade treatments on the photosynthetic capacity, chlorophyll fluorescence, and chlorophyll content of Tetrastigma hemsleyanum Diels et Gilg. Environmental and Experimental Botany, v.65, p.177182, 2009. http://dx.doi.org/10.1016/j.envexpbot.2008.12.008

Deng, Y.; Li, C.; Shao, Q.; Ye, X.; She, J. Differential responses of double petal and multi petal jasmine to shading: I. Photosynthetic characteristics and chloroplast ultrastructure. Plant Physiology and Biochemistry, v.55, p.93-102, 2012. http://dx.doi.org/10.1016/j. plaphy.2012.03.006

Ferreira, D. F. Sisvar: A computer statistical analysis system. Ciência e Agrotecnologia, v.35, p.1039-1042, 2011.

Gomes, A. R. M.; D’Ávila, J. H. T.; Gondim, R. S.; Bezerra, F. C.; Bezerra, F. M. L. Estimativa de evapotranspiração e coeficiente de cultivo da Heliconia psittacorum L x H. spathocircinada (Arist) cultivada em ambiente protegido. Ciência Agronômica, v.37, p.13-18, 2006.

Ivanov, A.; Hurry, V.; Sane, P.; Öquist, G.; Huner, N. Reaction centre quenching of excess light energy and photoprotection of photosystem II. Journal Plant Biology, v.51, p.85-96, 2008. http:// dx.doi.org/10.1007/BF03030716

Junqueira, A. H.; Peetz, M. S. O setor produtivo de flores e plantas ornamentais do Brasil, no período de 2008 a 2013: Atualizações, balanços e perspectivas. Revista Brasileira de Horticultura Ornamental, v.20, p.115-120, 2014. http://dx.doi.org/10.14295/rbho.v20i2.727

Paulino, A. S.; Albuquerque, A. W.; Moura Filho, G. M.; Pereira, F. R. Helicônia "Golden Torch": Produtividade e qualidade póscolheita sob diferentes fontes e doses de silício. Revista Brasileira de Engenharia Agrícola e Ambiental, v.17, p.615-621, 2013. http:// dx.doi.org/10.1590/S1415-43662013000600007

Rodríguez, F. M. S. Cultivo del género heliconia. Cultivos Tropicales, v.34, p.24-32, 2013.

Silva, A. de S. Adubação nitrogenada e potássica no cultivo de helicônia cv. Golden Torch. Bom Jesus: UFPI, 2013. 41p. Dissertação Mestrado

Unemoto, L. K.; Faria, R. T.; Assis, A. M.; Lone, A. B.; Yamamoto, L. Y. Cultivo de bastão-do-imperador sob diferentes espaçamentos em clima subtropical. Ciência Rural, v.42, p.2153-2158, 2012. http:// dx.doi.org/10.1590/S0103-84782012005000094 